\title{
Aloe vera in dentistry- a review
}

\author{
Monica.B, ${ }^{1}$ Monisha. ${ }^{2}$ \\ Intern, saveetha dental college, India
}

\begin{abstract}
Aloevera has been long time used for its many beneficial properties. It is still in use for its wide range for ailments. It promotes more rapid wound healing and pain relief. It has anti bacterial, anti viral, antifungal, antioxidant effect. Aloevera has shown multiple uses in dentistry. This review article is about the different use of aloevera in field of dentistry and its side effect.
\end{abstract}

Keywords: aloevera, a.barbadensis, a.arborescens.

\section{Introduction:}

Aloevera derives its name from the Arabic word "alloeh" and from Latin word "vera" meaning shinning bitter substance and true respectively [1]. It looks similarly to cactus but it isn't. The plant is member of Lilly family which includes garlic and onion. It usually grows only in the warm tropical areas and cannot survive freezing temperatures [2]. Two species of aloevera A. barbadensis and A. arborescens having a slight different composition are used in medicine [3]. The leaves of the plant consist of two different parts namely parenchymal tissue which is the inner portion of the leaves which produces mucilage or gel which is clear and tasteless. And the other part is group of specialized cells known as pericyclic tubules which is seen beneath the other green rind of the leaf. These cells produce exudates which consist of bitter yellow latex with powerful laxative actions [4].

\section{Composition:}

Gjerstad found that the leaves of the aloevera plant consist of $99.5 \%$ of water and $0.0013 \%$ protein [5]. Rowe and parks has noted fructose, ash, amylase [6]. Aloevera contains around 75 active ingredients which includes vitamins, enzymes, sugars, minerals, lignin, saponins, salicyclic acids and amino acids; numerous monosaccharide's and polysaccharides; several inorganic substances which includes enzymes such as acid phosphates, alkaline phosphates, amylase, lactic dehydrogenase, lipase. And numerous organic compounds such as aloin,baraloin and emodin[7]. Aloevera also consist of aluminum, boron, barium, calcium, iron, magnesium, sodium, phosphorous, silicon and strontium [8].

\subsection{Healing properties:}

\section{Biological effects:}

Glucomannan, amannose rich polysaccharide and gebbeerillin (growth hormone), interacts with growth factor receptors on the fibroblast stimulates its activity and proliferate, which in turns significantly increases collagen synthesis [9].

\subsection{Moisturizing and anti aging effect:}

Moisturizing effects appears due to water and polysaccharides components creating a jelly like consistency which holds the water within the mix and minimizes its evaporation when applied to drying tissues and humectants properties which retains moisture in the tissues[10]. Aloe stimulates fibroblast which produces the collagen and elastin fibers which make skin more elastic and less wrinkled [9].

\subsection{Anti inflammatory effects:}

Aloe Vera inhibits the cyclooxygenase pathway and reduces prostaglandin E2 production from arachidonic acid [9]. Hanley et al reported that aloevera extract decreases inflammation by $48 \%$ in a rat adjuvant-induced arthritic inflammatory model [11].

\subsection{Antibacterial, antifungal, antiviral effects:}

Streptococcus pyogenes and streptococcus faecalis are two microorganisms which have been inhibited by the aloevera gel [12]. It enhances the wound healing process by eliminating the bacteria which contributes to inflammation [13].aloevera has found to inhibit the growth of Candida albicanas [12]. It has an antiviral effect against herpes simple's virus type 1 and 2 and also against varicella-zoaster, influenza virus and pseudorabiees virus [14]. 


\subsection{Protective effects:}

Aloevera gel administered to the skin exposed to UV and gamma radiation will generate an antioxidant protein, metallothionenin in the skin which scavenges hydroxyl radicals and prevent suppression of superoxide dismutase and glutathione peroxidase in the skin. Aloe Vera gel has protective effect against radiation damage to the skin [9].

\subsection{Antioxidant effect:}

Isorabaichromone, feruoylaloesin and p-coumaroylalosin from aloe showed patent free radical and superoxide anion-scavenging activites in an assasy using lipid per oxidation rat liver microsomal system as the free radical generator [15].

\subsection{Effect on the immune system:}

Alprogen inhibits calcium influx into the mast cells hence inhibiting the antigen-antibody mediated release of histamine and leukotrine from the mast cells. Acemannan stimulates the synthesis and release of IL-1 and tumor necrosis factor from macrophages which initiates immune attack which results in necrosis and regression of the cancerous cells [9].

\subsection{Antiseptic effect:}

Luperol, salicyclic acid, urea, nitrogen, cinnamonic acid, phenols and sulfur present in aloevera have inhibitory action on fungi, bacteria and virus [9].

\subsection{Anticariogenic activity:}

\section{Dental application of aloevera}

Mohammadmehdi fani found that alovera gel shows bactericidal activity against both cariogenic and periodontopathic bacteria [16]. The aloe Vera gel was initially evaluated by the disk diffusion method using 20 isolates of s.mutans, undiluted aloe Vera gel produced significant growth inhibition zones against all the oral bacteria tested [16].

\subsection{Lichen planus:}

It is a chronic inflammatory disorder affects the skin and oral mucosa. Since it is chronic in nature no definite cure has been discovered. Topical application of aloevera 3 times a day provides the pain relief, improves the oral lesion and quality of the patient $[17,18]$. Steroids are the most recommended treatment in the case of lichen planus however prolong use of steroids is associated with multiple systemic complications which provide aloe Vera an added advantage due to its minimal side effects also when compared with triameinolide better results were obtained with topical aloevera[19].

\subsection{Apthous stomatitis:}

Aloevera is effective in decreasing the recurrent apthous stomatitis pain and wound size and reduces the wound healing period [20,21].aloe and myrrh based stomatitis. Aloe Vera was found superior to myrrh in decreasing the ulcer size erythema and exudation [22]. Us food and drug administration has also found derivative of aloe Vera an effective treatment alternative in treating oral ulcer [23].

\subsection{Oral submucous fibrosis:}

Aloe Vera gel is effective in case of osmf when compared with antioxidant better improvement in mouth opening and reduction of burning symptoms was found [24].

\subsection{Burning mouth syndrome:}

It is a painful condition of multifactorial etiology usually described as burning sensation in tongue, lips, palate or throughout the mouth. There may be numbness on the tip of the tongue or in the mouth, bitter or metallic changes in the taste and dry or sore mouth. In this condition to assess the efficacy of aloevera in this condition, patient was divided into 3 groups. Group I tongue protector which consist of a transparent, low density poly ethylene sheath covering the tongue from the tip to the posterior third this is worn for 15 min 3times a day. Group II is tongue protector and $0.5 \mathrm{ml}$ av at $70 \% 3$ times a day And group III tongue protector and $0.5 \mathrm{ml}$ placebo 3 times a day. This treatment is continued for 3 months. When compared finally improvement was more for group II. Hence concluding that aloe Vera is effective for treating patient with burning mouth syndrome [25]. 


\subsection{Wound healing:}

Polysaccharides contained in the gel of the leaves, promote wound healing. Acemannan induced cell proliferation and stimulated keratinocytes growth factor 1(KGF-1) vascular endothelial growth factor (VEGF) and type 1 collagen expression [26]. Aloevera when inserted into an extraction socket; it is very beneficial because of its powerful healing properties. When aloevera were used in the extraction socket it reduces the incidence of occurrence of dry socket. A retrospective study of 587 patients whose extraction sites had been treated with clincamycin-soaked gel foam in addition, a prospective study was performed with freeze-dried pledgeets containing acemannan hydrogel immediately after extraction; reported that aloe vera pledgets reduce the incidence of alveolar osteitis significantly compare to clindamycin-soaked gel form[27].

\subsection{Pulpotomy of primary tooth:}

Pulpotomy refers to removal of coronal pulp once removing the coronal pulp with a spoon excavator and then irrigate with saline and finally when hemorrhage is controlled with wet cotton pellets. Aloe Vera gel is applied to the remaining pulp stumps followed by non eugenol cements and permanent restoration was found to be effective and patient is also free from symptoms and prevent reinfection. There was no evidence of abscess, mobility, pain or swelling was found. Patient was followuped after 30 days and 60 days to check vitality of teeth [28].

\subsection{Obturation of primary teeth:}

A study was done to evaluate the antimicrobial effectiveness of root canal filling materials.6 root canal filling materials aloevera, sterile water with zinc oxide and eugenol, zinc oxide, eugenol with aloe Vera, calcium hydroxide and sterile water and calcium hydroxide, aloevera and idoform (metapex) and vaselin (control) were used. Aloevera with sterile water found to have maximum antimicrobial activity [29].

\subsection{Aloevera toothpaste and gel:}

Studies done using aloevera tooth pastes has shown that the aloevera are equally effective against candida albicans, streptococcus mutans, lactobacillus acidophiles, enterococcus faecalis, prevotella intermedia and peptostreptococcus anaerobies. Aloevera tooth gel has shown enhanced antibacterial effect against s.mitis [30]. Tooth paste containing aloe Vera showed improvement in gingival and plaque index scores as well as microbiological counts compared with placebo dentifrice( compared to those achieved with tooth paste containing triclosan)[31].

\subsection{Intracanal medicament:}

Aloevera has shown antimicrobial effect against resistant microorganism found in the root canal. In many cases the causes for the failure of endodontic treatment is due to persistent or secondary intraradicular infection [32]. It has been found enterococcus faecalis has been associated with failure of root canal therapy. Suresh Chandra conducted a study on in vitro antibacterial efficacy of aloe Vera extract on resistant antimicrobial strains in endodontic. The antimicrobial effect of alcohol, chloroform exacts of aloevera gel was investigated on different strains of bacteria and yeasts. This study has concluded aloevera show significant zone of inhibition against E. faecalis [33].

\subsection{Disinfection of irrigation units:}

Waterlines of dental units have large amount of microorganism and are the source of the infection hence proper disinfection of these pipelines is most important. In a study dental unit water lines were treated with 3 disinfectant solutions to compare the efficacy. (Aloe era, 10\% hydrogen peroxide and 5\% sodium hypochlorite). Each disinfectant was used in higher concentration and their inhibiting effect was compared by obtaining baselines water samples. Aloe Vera solutions were found to be most effective in decreasing the microbial colonies [34].

\subsection{Disinfectant of gp cones:}

Aloevera gel was found to be effective in decontaminating gp cones within 1 min under sterile condition some gp points were placed in thioglycolate broth and incubated for 24 hours and some new gp points were taken along side and decontaminated for $1 \mathrm{~min}$ in $90 \%$ aloe vera gel then the cones was removed from the gel and cleaned with sterile gauze and incubated in thioglycolate broth for 24 hours. Both the tubes were closely monitored for turbidity. A Gp cone which not decontaminated and directly placed in broth develops turbidity. Gp cones decontaminated with aloe vera placed in the broth remain clear even after 24 hours. Hence indicating absence of microbial growth [35]. 


\subsection{Aloevera in periodontal disease:}

Periodontitis is an infectious inflammatory disease. Bacteria modulate the inflammatory response and alter the periodontal disease. Now a day's various host response modulation therapies and local drug therapies have been developed to block the pathway responsible for periodontal tissue breakdown [36]. Aloe Vera can be used as local drug delivery system since it is easily available and easily applicable with minimal equipments. Sub gingival administration of aloe Vera gel will results in improvement of periodontal condition. Aloe contains anthraquinones which are chemical compounds used in healing and arresting pain because they are anti inflammatory in nature. Aloe veratooth gel does not contain the abrasive elements which are found in commercial tooth paste. Application directly to the site of periodontal surgery along with periodontal dressing will reduce the duration of wound healing [37]. Aloevera was also tried as a mouthwash which can be used asan adjunct to mechanical therapy for treating plaque induced gingivitis [38, 39].

\section{Contraindication:}

Aloe Vera should be used cautiously in pregnancy, lactating mothers [40].

\subsection{Tropical:}

Aloe Vera may causes redness, burning and stingling sensation allergic reactions are due to anthraqunions such as alone and barbaloin [9].

\subsection{Systemic:}

Ingestion of aloe Vera is sometime associated with diarrhea, electrolyte imbalance, kidney dysfunction and conventional drug interactions [41]. Prolong use has been reported to increases the risk of colorectal cancer [9]. Aloe Vera in children under 10 years of age is restricted [42]. Increased hypoglycemia might be seen in conjunction with oral antidiabetics or insulin in case of diabetic patients [43]. Aloe Vera gel is not recommended in combination with antidiabetic, diuretic or laxative drugs; digoxin [44].

\section{Conclusion:}

Aloevera plays the promising role in various branches of dentistry in future. Future studies should be aimed to determine the optimal concentration, time of application and its effect on oral cavities and evaluation of potential side effects and long term use should be evaluated.

\section{Reference:}

[1]. Current perspectives on the use of aloe Vera in dentistry". Erika tayal; divesh sardana, k.R. indusekar, bhavana G, saraj and neha sheoran.

[2]. Newall CA, Anderson LA, Phillipson JD " herbal medicines a guide for health care professionals. London: the pharmaceuticals press.1996.

[3]. Wintola OA, Summonu TO, afolayan AJ. " the effect of aloe ferox mill in treatment of ioperamide-induced constipation in wistar rats. BMC gasto enterol 2010;10:95

[4]. Richard L. Wynn. Aloevera gel:update for dentistry- general dentistry 2005;

[5]. Richard L. wynn. Aloe vera gel: update for dentistry- general dentistry 2005;jan-feb 6-9.

[6]. Rowe TD, parks LM. A phytochemical study of aloevera leaf. J AM PHARm assoc 1941;30:262-265

[7]. Mayes SM. Lichen planus-report of successful treatment with aloevera. Gen dent 1999;47:268-272.

[8]. Yamaguchi I et al. components of the gel aloevera(L) burm.F.biosic biotechnol biochem 1993;57:1350-1352

[9]. Renu et al. aloevera and its uses in dentistry. Indian J dent adv 2011;3(4):656-658.

[10]. Meadows TP. Aloe as a humectants in new skin prepration cosmetic tolerates 1980; 95: 51-56

[11]. Hanley DC, Solomon WA, saffron B, davis RM. The evaluation of natural substances in the treatment of adjuvant arthritis. J AM. Podiatry assoc 1982;72:275-284

[12]. Heggers JP, piniless GR, Robson MC.dermoid aloe/ alovera gel; comparision of the antimicrobial effects J AM MED TEChnol 1979;41:293-294

[13]. Heggers JP,kucukcelibi A, stabenou CJ xo F, Broemeling LD, robson MC, winters WD. Wound healing effects of the aloe gel and other topical antibacterial agents in rat skin phytotherapy 1995;9:455-457

[14]. Sysdiskis RJ, owen DG, lohr JL, rosler KH, blonster RN. Inactivation of enveloped viruses by anthraquinones extracted from plants. Antimicrob agent chemother 1991;35:2463-2466.

[15]. Yagi A, kabash A, okamura N, haraguchi H, moustafa SM, khalja TI. Antioxidant, free radical scavenging and anti inflammatory effects of loesin derivatives in aloevera planta med 2002;68:957-960.

[16]. Mohammadmehdi fani and jamshid kohanteb. Inhibitory activity of aloevera gel on some clinically isolated cariogenic and periodontopathic bacteria journal of oral science 2012;54(1):15-21

[17]. Radwan-oczko M. topical application of drugs used in treatment of oral lichen planus lesions. Adv clin exp med 2013;22:893-898.

[18]. N Salazar-sanchez P, lopez- jornet, F Camacho-alonso m, sanchez-seles." Efficacy of topical aloevera in patients with oral lichen planus: a randomized double blind study.journal of oral path med.2010; 39: 735-740.

[19]. Reddy RL, reddy RS, Ramesh T, singh TR, swapna LA, laxmi NV. Randomized trial of alovera gel vs triamcinolone automide ointment in the treatment of oral lichen planus. Quintessence int.2012;43:793-800

[20]. Garnick JJ, singh B, wenkley G. effectiveness of a medicament containing silicondioxide, aloe and allantoin on apthous stomatitis. Oral surg oral med oral pathol oral radiol endod.1998;86:550-6.

[21]. Sudarshan R, annigeri G, sree vijayabala G. aloe vera in dentistry. Indian j stomatol.2013;4:45-47. 
[22]. L Mansour G, ouda S, shaker A. clinical efficacy of new aloevera and myrrh-based oral mucoadhesive gels in the management of minor recurrent apthous stomatitis: a randomized double blind, vehicle- controlled study. J oral patho med.2013;25.doi: 10.1111/jop. 12130 .

[23]. Jacob, Julie A.oral ulcers remedy gets FDA clearance. J. AM. Dent assoc.1994;125(10):1308-1310

[24]. Sudharshan R, annigeri RG, sree vijayabala G. aloe vera in the treatment for oral submucous fibrosis- a preliminary study. J oral pathol med.2012;41:755-61.

[25]. Lopez-jornet P, cannacho- alonsof, Molino-pagan. D. prospective, randomized, double-blind, clinical evaluation of aloe vera barbadenisis, applied in combination with a tongue protector to treat burning mouth syndrome. J oral pathol Med.2013;42: 295-301.

[26]. Jettanacheawchankit S, sasithanasote s, sangvanich P,banlunara $w$, thenyakitpisal P. acemannan stimulates gingival fibroblast proliferation; expressions of keratinocyte growth factor-1,vascular endotheilial growth factor and type 1 collagen and wound healing. J pharmacol sci.2009;109:525-31

[27]. Poor MR, hall JE, poor AS. Reduction in the incidence of alveolarosteitis in patients treated with the salicept patch containing acemannan hydrogel. J oral maxillafac surg.2002;60:374-379.

[28]. Gupta N, bhat M, devi P, girish aloevera: a natures gift to children. Int J CLIN PEDIATR DENT.2010;3;87-92.

[29]. Kriplani R, hosar N, Baliga MS, Kulkarmi P, shah N, yeluri R. comparative evaluation of antimicrobial efficacy of various root canal filling materials along with aloe vera used in primary teeth: a microbiological study. J CLIN PEDIATR DENT.2013;37:25762

[30]. George det al. comparative evaluation of the antimicrobial efficacy of aloe vera tooth gel and two popular commercial tooth pastes: an in vitro study general dentistry.2009;238-241.

[31]. Pradeep AR, agarwal E, Naik SB. Clinical and microbiologic effects of commercially available dentrifice containing aloe vera a randomized controlled clinical trial. J PERIODONTOL.2012;83:797-804

[32]. J.F siquira JR. aetiology of root canal treatment failure: why well treated teeth can fail. International endodontic journal $2001 ; 34(1) 10$

[33]. B.suresh Chandra and arun $\mathbf{J}$ kumar in vitro antibacterial efficacy of aloevera extract on resistant antimicrobial strains in endodontics.

[34]. Pareek S, nagaraj A, Sharma P,atri M et al. disinfection of dental unit water line using aloe vera: in vitro study. Int j dent 2013

[35]. Athiban pp, borthakur BJ, ganesan s, swathika B. evaluation of antimicrobial efficacy of aloe vera and its effectiveness in decontaminating gutta percha cones. J conserve dent.2012;15:246-8.

[36]. Kiloy.w.j. et al. controlled local delivery of antimicrobials in the treatment of periodontitis. Dent clinical north am 1998;43:263283.

[37]. Bhat et al. aloe vera natures soothing healer to periodontal disease. J Indian soc periodontal 2011;15:205-209.

[38]. Ajmeera N, chatterjee A, goyal v. aloevera: its effect on gingivitis. J ind soc periodontal 2013;17:435-8.

[39]. Chandrahas B, jayakumar a et al. a randomized double blind clinical study to assess the antiplaque and antihgingivitis efficacy of alovera mouth rinse. J Indian soc periodontal 2012;16:543-8

[40]. Moore T.E. the $m$ and m's of aloevera is it for dentistry. Joklsa dent assoc 2001;9:30-36

[41]. Bondreau MD, beland FA. An evaluation of the biological and toxicological properties of aloe barbedensis(miller), aloevera. Journal of environmental science and health 2006 partc;24:103-15431.aloevera side effects and cautions. National centre for complememtary and alternative medicine.

[42]. Bisset NG, bocan raton, FL,CRC. Press sennae folium. IN;max wichtl's herbal drugs and phytopharmaceuticals 1994;463-69

[43]. World health organization (who), ed who monographs on selected medical plants geneva, Switzerland:world health organization.1991.

[44]. Brinker F. herbcontraindications and drug interactions. $2^{\text {nd }}$ ed: electric medical publications; 1998. 